\title{
The Effect of Bullying on Depression in Adolescents: A Meta-Analysis
}

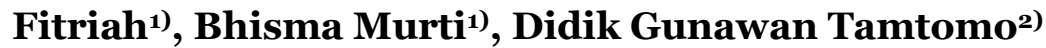 \\ 1)Masters Program in Public Health, Universitas Sebelas Maret \\ ${ }^{2)}$ Faculty of Medicine, Universitas Sebelas Maret
}

\section{ABSTRACT}

Background: Bullying can cause feelings of insecurity in adolescents with reduced social support and the need for acceptance in the environment and peers is not fulfilled. $16.8 \%$ of teenagers who are involved in cyberbullying have a risk of depression. Depressive disorders are common in adolescents, with a prevalence approaching $5.6 \%$ in adulthood. This study aims to examine the effect of bullying on depression in adolescents.

Subjects and Method: This research is a meta-analytical study and a systematic review. The articles used were obtained from several electronic databases including PubMed, Science Direct and ProQuest. The articles used in this study are articles that have been published from 2010-2021. The author defines the eligibility criteria using the PICO model: population is adolescents, intervention is bullying, comparison is non bullying and outcome is depression. The research data search process used the search words "bullying and depression", "bullying and depression and adolescent and crosssectional study", "bullying and depression and adolescent and cross-sectional study and adjusted odd ratio". Articles were collected using the PRISMA diagram, and analyzed using the Review Manager 5.4 application.

Results: The results of the meta-analysis study in this study contained 9 articles consisting of Saudi Arabia, Malaysia, Seychelles, United States, Massachusetts, Bosnia and Canada. Bullying can increase the risk of depressive disorder in adolescents $(\mathrm{aOR}=2.43 ; 95 \% \mathrm{CI}=1.87$ to $3.15 ; \mathrm{p}<0.001)$, with $\mathrm{I}^{2}=96 \%$.

Conclusion: Bullying affects the risk of depression in adolescents.

Keywords: teens, bullying, depression

Correspondence:

Fitriah. Masters Program in Public Health, Universitas Sebelas Maret. Jl. Ir. Sutami 36A, Surakarta 57126, Central Java, Indonesia. Email: fitriahbaharuddin@gmail.com. Mobile: +6282350701936.

Cite this as:

Fitriah, Murti B, Tamtomo DG (2021). The Effect of Bullying on Depression in Adolescents: A MetaAnalysis. J Health Promot Behav. 06(02): 112-121. https://doi.org/10.26911/thejhpb.2021.06.02.04.

(c) (i) (-) Journal of Health Promotion and Behavioris licensed under a Creative Commons

cc) Attribution-NonCommercial-ShareAlike 4.0 International License.

\section{BACKGROUND}

Depression is a mental disorder that often occurs in society. Starting from stress that is not overcome, then a person will enter a phase of depression. Depressive disorders often occur in adolescents, with a prevalence approaching $5.6 \%$ at the adult level (Schwartz in Allgaier, 2014). The World Health Organization (2010) estimates that
7.4\% of global DALYs (Disability Adjusted Life Year) are caused by disorders in the mental and behavioral disorders category. Major depressive disorder accounted for $34.12 \%$ of DALYs in the mental and behavioral disorders category. WHO also says depression has claimed the lives of more than 850,000 people in a year. The average number of cases of depression affects 
teenagers and adults in the age range of 1529 years.

The Research and Development Agency of the Ministry of Health in collaboration with WHO conducted a Schoolbased Health Survey. The results of the 2015 survey stated that the percentage of students feeling lonely was $46.01 \%$, worried too much 42.18\%, wanted to commit suicide $5.2 \%$ and had been bullied in the last 30 days by 20.6\%.

Bullying can have serious/negative effects on children's mental health and wellbeing (Herman, et al., 2017). The prevalence of bullying victimization was at least 1 day in the last 30 days (24.5\%) in Bangladesh and (50.9\%) in Nepal (Rahman et al., 2020). Bullying has several detrimental effects, such as emotional, social and physical harm (Nansel et al., 2004). In addition, bullying also has long-term impacts such as difficulty adapting in the future, even suicidal ideation and suicide attempts (Låftman et al., 2018).

Razak et al. (2019) states that adolescents who have been bullied have a 3 times greater risk of experiencing depression compared to those who have not. Bullying has a relationship with mental health problems (Al-Buhairan et al., 2017). Children and adolescents who are bullied (72.3\%) will experience depression (Hansson et al., 2020).

Various studies have been conducted, to see the effect of bullying on depression in adolescents. Further analysis is needed to reach a convincing conclusion.

\section{SUBJECTS AND METHOD}

\section{Study Design}

This was a meta-analytical study and a systematic review. The articles used were obtained from several electronic databases including PubMed, Science Direct and ProQuest. The articles used in this study are articles that have been published from 20102021.

The research data search process was conducted using the search terms "bullying and depression", "bullying and depression and adolescent and cross-sectional study", "bullying and depression and adolescent and cross sectional study and adjusted odd ratio".

\section{Population and Sample}

The articles included in this study are the texts of articles with observational studies that have been published from 2010-2021. Selected articles discuss the effect of bullying on depressive disorders. The articles used are articles published in English. The research sample is a teenager. The research data are multivariate. The final results of the study were reported using the adjusted odds ratio (aOR).

The researcher defines the eligibility criteria using the PICO model: population is adolescents, intervention is bullying, comparison is non bullying and outcome is depression.

\section{Inclusion and Exclusion Criteria}

The exclusion criteria in this study were

a. The study was conducted using RCT, case control, quasi-experimental, protocol study, and pilot study.

b. Articles published in languages other than English.

c. Not a multivariate analysis study.

\section{Operational Definition of Variables}

Bullying is aggressive behavior that is carried out consciously so that individuals feel distress that is carried out for a long time and repeatedly in relationships where there is an imbalance of power or strength can cause feelings of insecurity in adolescents.

Depression is a feeling disorder characterized by inability to make decisions, impaired concentration, lack of enthusiasm for life, moodiness and deep sadness that continues to cause loss of passion for life. 
Fitriah et al./ Bullying on Depression in Adolescents

\section{Data Analysis}

The data processing was carried out using the Review Manager (RevMan 5.4) by calculating the effect size and heterogeneity values to determine the combined study model and form the final result of the forest plot meta-analysis (Wijiwinarsih et al., 2019 in Karlinda et al., 2019).

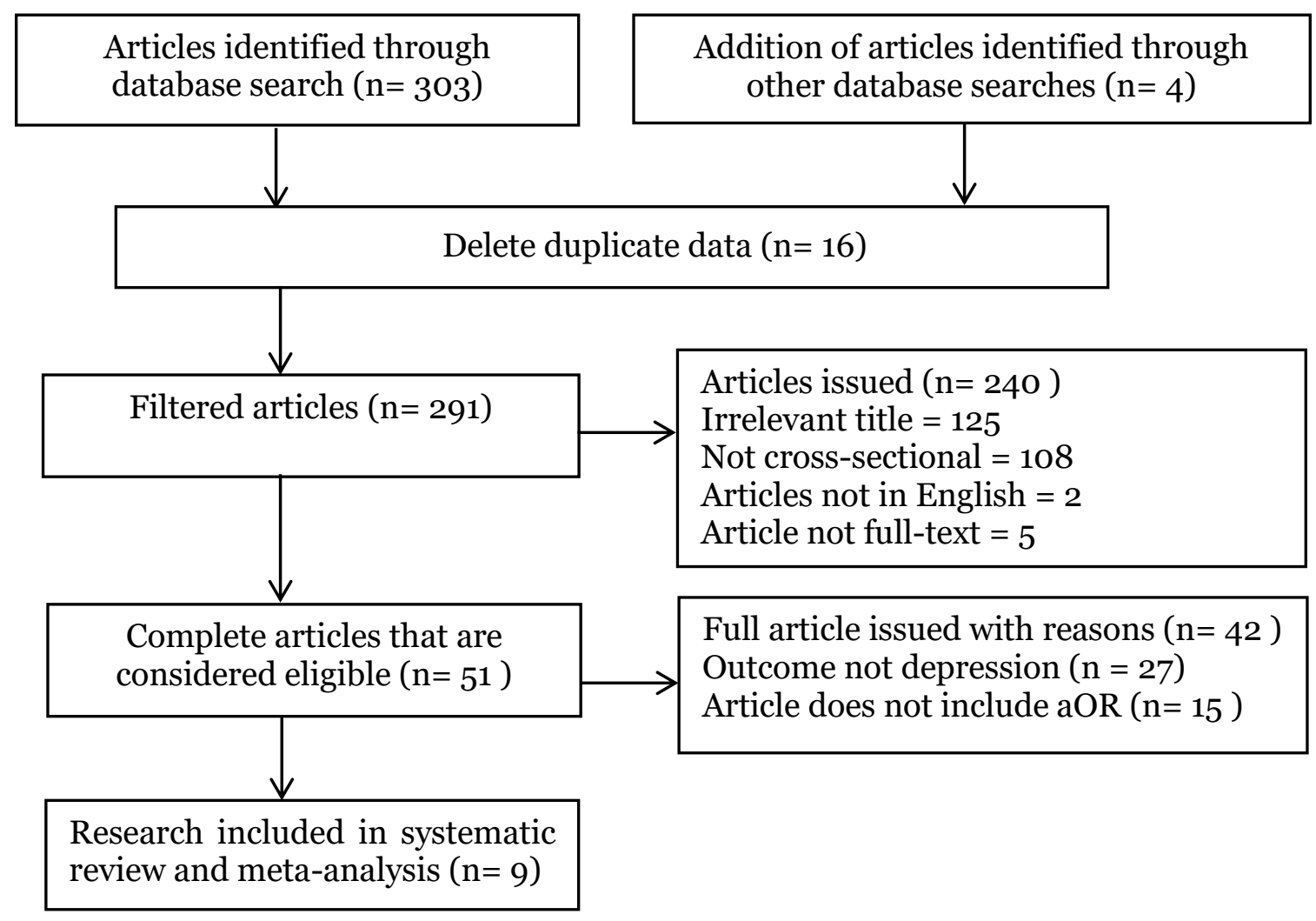

Figure 1. Flowchart of the review process

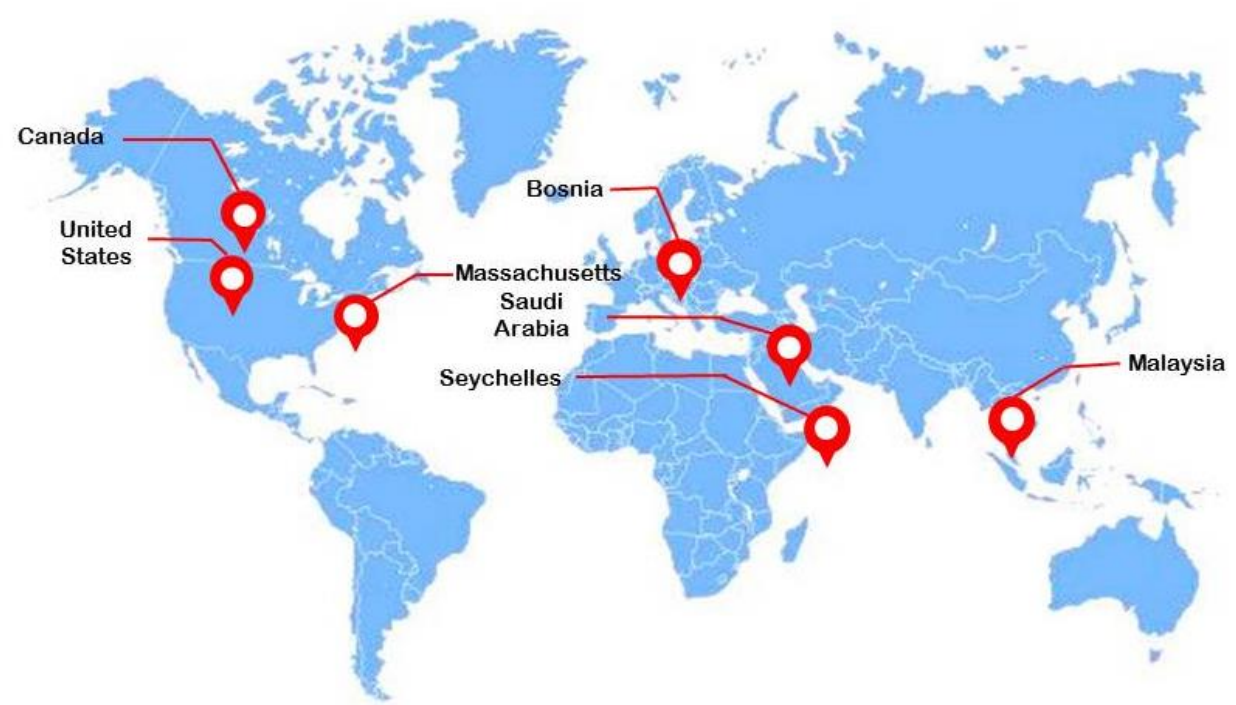

Figure 2. Map of the research area the influence of bullying on depression 
Fitriah et al./ Bullying on Depression in Adolescents

\section{RESULTS}

The process of finding articles using a journal database is shown in Figure 1. Figure 2 shows the areas where articles were published according to the inclusion criteria. The articles in this study come from 7 countries, namely Saudi Arabia, Malaysia,
Seychelles, United States, Massachusetts, Bosnia and Canada.

\section{Summary of source articles}

Table 1 shows that there are 9 observational study articles on bullying that have an effect on depression in adolescents.

Table 1. The effect of bullying on depression

\begin{tabular}{lcccc}
\hline \multicolumn{1}{c}{ Author (year) } & Country & aOR & 95\% CI & p \\
\hline Al-Buhairan et al., (2017) & Saudi Arabia & 2.66 & $2.39-2.95$ & $<0.001$ \\
Razak et al., (2019) & Malaysia & 2.98 & $2.77-3.21$ & $<0.001$ \\
Tan et al., (2019) & Malaysia & 1.28 & $1.10-1.49$ & 0.002 \\
Kaur et al., (2014) & Malaysia & 1.79 & $1.60-1.99$ & $<0.001$ \\
Wilson et al., (2012) & Seychelles & 1.63 & $1.27-2.09$ & $<0.001$ \\
Selkie et al., (2015) & United States & 4.5 & $1.1-1.87$ & 0.04 \\
Schneider et al., (2012) & Massachusetts & 4.38 & $3.76-5.10$ & 0.002 \\
Pranjić and Bajraktarević, (2010) & Bosnia & 2.63 & $1.70-4.05$ & $<0.001$ \\
Lemstra et al., (2012) & Canada & 3.1 & $2.4-3.8$ & $<0.001$ \\
\hline
\end{tabular}

\section{Fores plot}

Figure 3 shows the results of a forest plot of the effect of bullying on depression in adolescents. The results of the forest plot show that adolescents who are victims of bullying can increase depression as much as
2.43 times compared to adolescents who do not experience bullying, and statistically significant $(\mathrm{p}=<0.001)$. The heterogeneity of the research data shows $\mathrm{I}^{2}=96 \%$ so that the distribution of the data is declared heterogeneous (random effect model).

\begin{tabular}{|c|c|c|c|c|c|c|c|c|}
\hline Study or Subgroup & log[Odds Ratio] & SE & Weight & $\begin{array}{c}\text { Odds Ratio } \\
\text { IV, Random, } 95 \% \mathrm{Cl}\end{array}$ & & $\begin{array}{r}\text { Odds F } \\
\text { IV, Randon }\end{array}$ & $\begin{array}{l}\text { Ratio } \\
\mathrm{m}, 95 \% \mathrm{Cl}\end{array}$ & \\
\hline Al-Buhairan 2017 & 0.9783 & 0.0546 & $12.9 \%$ & $2.66[2.39,2.96]$ & & & $=$ & \\
\hline Kaur 2014 & 0.5822 & 0.0573 & $12.9 \%$ & $1.79[1.60,2.00]$ & & & - & \\
\hline Lemstra 2012 & 1.1314 & 0.1306 & $11.7 \%$ & $3.10[2.40,4.00]$ & & & $\rightarrow$ & \\
\hline Pranic 2010 & 0.967 & 0.2226 & $9.7 \%$ & $2.63[1.70,4.07]$ & & & $\rightarrow$ & \\
\hline Razak 2019 & 1.0919 & 0.0373 & $13.1 \%$ & $2.98[2.77,3.21]$ & & & - & \\
\hline Schneider 2012 & 1.477 & 0.0779 & $12.6 \%$ & $4.38[3.76,5.10]$ & & & - & \\
\hline Selkie 2015 & 1.5041 & 0.7188 & $2.7 \%$ & $4.50[1.10,18.41]$ & & & & \\
\hline $\operatorname{Tan} 2019$ & 0.2469 & 0.0773 & $12.6 \%$ & $1.28[1.10,1.49]$ & & & - & \\
\hline Wilson 2012 & 0.4886 & 0.1273 & $11.8 \%$ & $1.63[1.27,2.09]$ & & & $\rightarrow$ & \\
\hline Total $(95 \% \mathrm{Cl})$ & & & $100.0 \%$ & $2.43[1.87,3.15]$ & & & & \\
\hline \multicolumn{5}{|c|}{$\begin{array}{l}\text { Heterogeneity: } \text { Tau }^{2}=0.14 ; \mathrm{Chi}^{2}=198.86, \mathrm{df}=8(\mathrm{P}<0.00001) ; \mathrm{l}^{2}=96 \% \\
\text { Test for overall effect: } Z=6.62(P<0.00001)\end{array}$} & 0.01 & Non Bullying & Bullying 10 & 100 \\
\hline
\end{tabular}

Figure 3. Fores plot of the effect of bullying on depression 
Fitriah et al./ Bullying on Depression in Adolescents

Table 1. Summary of articles The Effect of Bullying on Depression

\begin{tabular}{|c|c|c|c|c|c|c|c|}
\hline $\begin{array}{l}\text { Penulis } \\
\text { (tahun) }\end{array}$ & Negara & $\begin{array}{l}\text { Desain } \\
\text { Study }\end{array}$ & Sample & $\begin{array}{c}\mathbf{P} \\
\text { Population }\end{array}$ & $\begin{array}{c}\text { I } \\
\text { Intervention }\end{array}$ & $\begin{array}{c}\mathrm{C} \\
\text { Compa- } \\
\text { rison }\end{array}$ & $\begin{array}{c}\text { O } \\
\text { Outcome }\end{array}$ \\
\hline $\begin{array}{l}\text { AlBuhairan et } \\
\text { al. (2017) }\end{array}$ & Saudi Arabia & $\begin{array}{l}\text { Cross- } \\
\text { sectional }\end{array}$ & 9.073 & Adolescents & $\begin{array}{l}\text { Bullying dan physical } \\
\text { violence }\end{array}$ & No bullying & Anxiety and depression \\
\hline $\begin{array}{l}\text { Razak et al. } \\
\text { (2019) }\end{array}$ & Malaysia & $\begin{array}{l}\text { Cross- } \\
\text { sectional }\end{array}$ & 27,399 & Adolescents & $\begin{array}{l}\text { di-bully setidaknya } \\
\text { sekali dalam } 30 \text { hari } \\
\text { terakhir }\end{array}$ & $\begin{array}{l}\text { Never been } \\
\text { bullied }\end{array}$ & Depression \\
\hline Tan et al. (2019) & Malaysia & $\begin{array}{l}\text { Cross- } \\
\text { sectional }\end{array}$ & 27,458 & $\begin{array}{l}\text { Students aged } \\
13 \text { to } 17 \text { years }\end{array}$ & Bullying victimization & $\begin{array}{l}\text { Tidak bullying } \\
\text { victimization }\end{array}$ & $\begin{array}{l}\text { Loneliness, truancy, suicide } \\
\text { plans, stress, anxiety and } \\
\text { depression }\end{array}$ \\
\hline $\begin{array}{l}\text { Kaur et al. } \\
\text { (2014) }\end{array}$ & Malaysia & $\begin{array}{l}\text { Cross- } \\
\text { sectional }\end{array}$ & 28,738 & $\begin{array}{l}\text { Students aged } \\
13 \text { to } 17 \text { years }\end{array}$ & $\begin{array}{l}\text { di-bully dalam } 30 \\
\text { hari terakhir }\end{array}$ & No bullying & Symptoms of depression \\
\hline $\begin{array}{l}\text { Wilson et al. } \\
\text { (2012) }\end{array}$ & Seychelles & $\begin{array}{l}\text { Cross- } \\
\text { sectional }\end{array}$ & 1.427 & Adolescents & Semua jenis bullying & No bullying & Depression \\
\hline $\begin{array}{l}\text { Selkie et al. } \\
\text { (2015) }\end{array}$ & United States & $\begin{array}{l}\text { Cross- } \\
\text { sectional }\end{array}$ & 265 & $\begin{array}{l}\text { Female adoles- } \\
\text { cents aged 18- } \\
25 \text { years }\end{array}$ & Cyberbullying & $\begin{array}{l}\text { No } \\
\text { cyberbullying }\end{array}$ & Depression \\
\hline $\begin{array}{l}\text { Schneider et al. } \\
\text { (2012) }\end{array}$ & Massachusetts & $\begin{array}{l}\text { Cross- } \\
\text { sectional }\end{array}$ & 20,406 & $\begin{array}{l}\text { Students aged } 9 \\
\text { to } 12\end{array}$ & Bullying victimization & $\begin{array}{l}\text { No bullying } \\
\text { victimization }\end{array}$ & $\begin{array}{l}\text { Symptoms of depression, } \\
\text { suicidal ideation, self-harm, } \\
\text { attempted suicide and } \\
\text { attempted suicide with medical } \\
\text { treatment }\end{array}$ \\
\hline $\begin{array}{l}\text { Pranjić and } \\
\text { Bajraktarević. } \\
\text { (2010) }\end{array}$ & Bosnia & $\begin{array}{l}\text { Cross- } \\
\text { sectional }\end{array}$ & 290 & Adolescents & Bully victims & No bullying & Depression and suicidal thought \\
\hline $\begin{array}{l}\text { Lemstra et al. } \\
\text { (2012) }\end{array}$ & Canada & $\begin{array}{l}\text { Cross- } \\
\text { sectional }\end{array}$ & 4.297 & $\begin{array}{l}\text { Students aged } 9 \\
\text { to } 15 \text { years }\end{array}$ & Bullying & No bullying & Depression \\
\hline
\end{tabular}




\section{Funnel plot}

Figure 4 shows that there is a publication bias which is indicated by the asymmetry of the right and left plots where there are 6 plots on the right and 3 plots on the left. The plot on the right of the graph appears to have a standard error between 0.8 and $o$ and the plot on the left has a standard error between 0.2 and 0 . Bias also occurs from the imbalance in the distance between studies on the right.

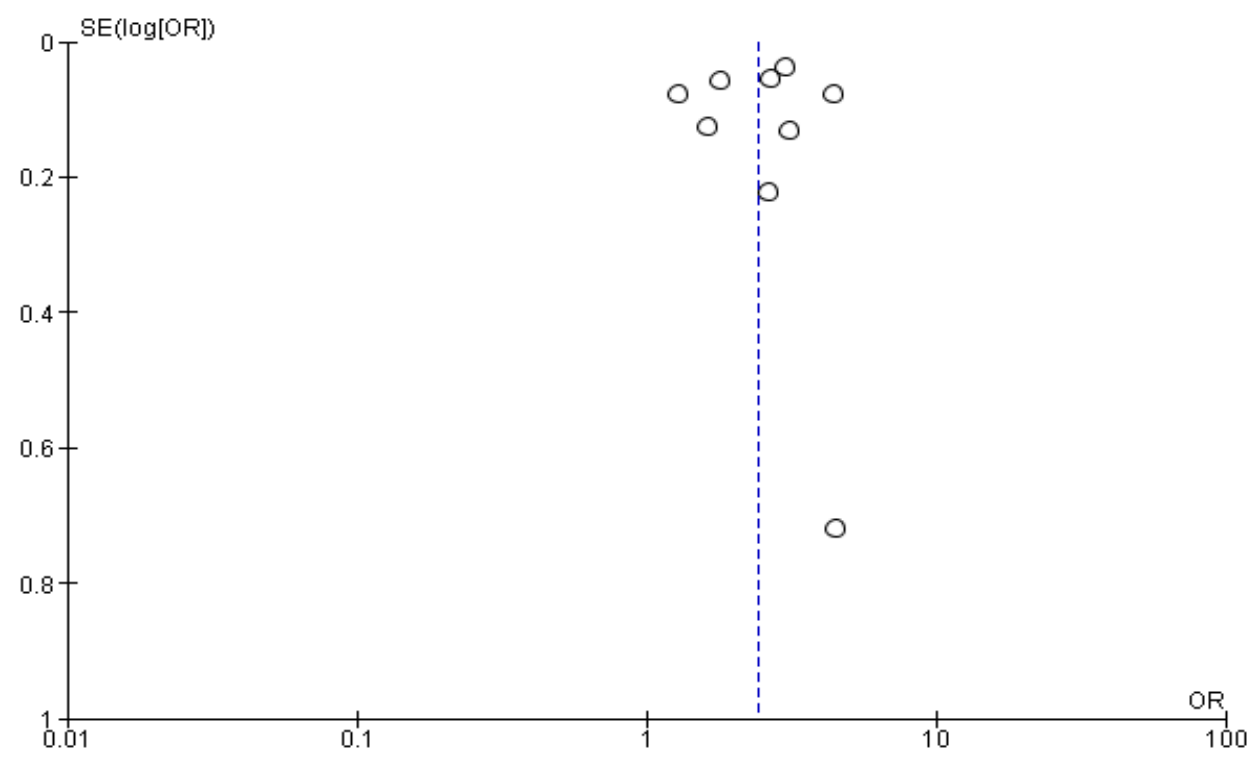

Figure 4. Funnel plot of the effect of bullying on depression

\section{DISCUSSION}

This systematic study and meta-analysis raised the theme of the effect of bullying on depression. The independent variable analyzed was bullying. This systematic review and meta-analysis research uses research that controls confounding factors which can be seen from the inclusion requirements of the study, namely using multivariate analysis and the statistical results reported are adjusted odd ratio (aOR).

The combined estimate of the association of each risk factor with the incidence of depression was processed using the RevMan 5.4 application. RevMan is used to perform a meta-analysis of the entered data and present the results graphically (Nindrea, 2016).

A systematic review and meta-analysis in this study was conducted with the aim of increasing the generalizability of the findings and obtaining convincing conclusions from the results of various similar studies regarding the effect of bullying on depression in adolescents. The results of the analysis are presented in the form of a forest plot and the possibility of bias is presented in a funnel plot.

Bullying has several detrimental effects, such as emotional, social and physical harm (Nansel et al., 2004). In addition, bullying also has long-term impacts such as difficulty adapting in the future, even suicidal ideation and suicide attempts (Låftman et al., 2018).

Both perpetrators and victims of bullying show a poor psychosocial impact, especially victims of bullying which have a much worse impact on life satisfaction (Weng et al., 2017). Children and adolescents who are bullied (72.3\%) will experience depression (Hansson et al., 2020). 
Depression that is not treated immediately will affect family relationships and work performance, resulting in poor coping skills such as low optimism and low self-esteem (Pettit et al., 2009).

The results of the analysis of 9 articles on the effect of bullying on depression. The results of the forest plot show that adolescents who have experienced bullying can increase depression by 2.43 times compared to adolescents who have not experienced bullying.

Wang et al., (2011) states that adolescents who have experienced bullying have a higher risk of depression than those who have not. Victims of bullying had a direct effect on depression ( $\beta=0.59 ; 95 \% \mathrm{CI}=0.52$ to $0.67 ; \mathrm{p}<0.001)$. Bullying increases the risk of depression in adolescents (Sudrajad et al., 2020) Victims of bullying are not able to be kind to themselves and also unable to resolve interpersonal conflicts effectively, thus they are more likely to be trapped in negative emotions and depression (Zhang et al., 2019; Le et al., 2016) suggested that students who were involved in bullying either as victims or victims of bullying experienced more symptoms of depression and psychological distress, and reported a higher likelihood of suicidal ideation than students who were not involved in bullying.

Naveed et al., (2019) stated that psychological distress significantly has a mediating effect between depression and bullying victims with an indirect effect size of 1.05 (95\% CI $=0.38$ to 0.78 ). $67 \%$ of bullying victims who experience stress show difficulty in psychosocial adjustment in several aspects of life, namely home, friendship, classroom learning and leisure activities.

Weng et al., (2017) stated that perpetrators, victims and victims of bullying showed worse psychosocial conditions than those who did not. In particular, victims and victims of bullying reported significantly poorer life satisfaction $(\mathrm{OR}=0.96$ and 0.96$)$. Bullies, victims and victims of bullying also experienced more anxiety and depression, although not statistically significant.

A meta-analysis study conducted by Jadambaa et al., (2019) showed that adolescents who were bullied had a 1.9 times higher risk of developing depressive disorders in later development. The high prevalence of anxiety disorders and depression is a contributor to the disease burden. $7.83 \%$ of anxiety disorders and $10.82 \%$ of depressive disorders are caused by exposure to bullying victims in childhood and adolescence.

The evidence base for the design and delivery of sustainable anti-bullying interventions in low- and middle-income countries is poor (Bowes et al., 2019). A systematic review study conducted by Sivaraman et al., (2018) shows that complex wholeschool anti-bullying interventions are effective for reducing bullying in high-income countries (HICs) but it cannot be assumed that these interventions will be effective in low-income countries. low- and middleincome countries (LMIC), where education systems and socio-cultural factors are very different. In particular, implementation research is needed to ensure successful adaptation and transfer of school-based interventions for youth across educational, cultural and socio-economic settings. Training materials, and support for anti-bullying interventions are considered expensive for schools or public service agencies with limited resources, which can be a barrier to implementing these interventions in lowresource settings.

Bowes et al., (2019) aims to develop and assess the feasibility of a youth-led school intervention to reduce bullying in adolescents in Indonesian secondary high schools. Interventions are developed in iterative stages: identifying promising interventions for the local context; formative 
participatory action research to contextualize proposed content and delivery; and finally two pilot studies to assess feasibility and acceptability in South Sulawesi and Central Java. The resulting intervention combines two key elements: 1) a studentdriven design to influence students prosocial norms and behaviors, and 2) a teacher training component designed to increase teachers' knowledge and self-efficacy for using positive disciplinary practices.

The first pilot study, collected data from 2,075 students in a waiting list controlled trial at four schools in South Sulawesi. The pilot study demonstrated good feasibility and acceptability of the intervention. Findings of reducing victims and acts of bullying when using a bullying scale (Form of Bullying Scale). In the second pilot study, a randomized waiting list controlled trial was conducted in eight schools in Central Java, involving a total of 5,517 students. The feasibility and acceptability are good.

Program effectiveness, like other whole-school programs focused on systemic behavior change, is likely to take more than a year to 'endure' (typically 2-3 school academic years), so it's important for schools involved to have a sustainable method of choosing either agents of student change, as well as in terms of access to facilitators. A full randomized controlled trial is needed to check the program's effectiveness and cost effectiveness.

\section{AUTHOR CONTRIBUTION}

Fitriah is the main author who selects the topic, searches for and collects research data; Didik Gunawan Tamtomo played a role in reviewing articles; Bhisma Murti plays a role in analyzing research data.

\section{FUNDING AND SPONSORSHIP}

This study is self-funded.
CONFLICT OF INTEREST

There is no conflict of interest in this study.

\section{ACKNOWLEDGMENT}

We thank the electronic database providers: PubMed, Science Direct and ProQuest.

\section{REFERENCES}

AlBuhairan F, Abbas OA, Sayed DE, Badri M, Alshahri S, Vries ND (2017). The relationship of bullying and physical violence to mental health and academic performance: A cross-sectional study among adolescents in Kingdom of Saudi Arabia. Int J Pediatr Adolesc Med. 4(2): 61-65. https://doi.org/10.1016/j.ijpam.2016.12.005.

Bowes L, Aryani F, Ohan F, Haryanti RH, Winarna S, Arsianto Y, Budiyawati H, et al. (2019). The development and pilot testing of an adolescent bullying intervention in Indonesia-the ROOTS Indonesia program. Global Health Action. 12(1): 1656905. https://doi.org/10.1080/16549716.2019.1656905.

Hansson E, Garmy P, Vilhjálmsson R (2020). Bullying, health complaints, and self-rated health among schoolaged children and adolescents. Int $\mathrm{J}$ Med Res. 48(2): 300060519895355. https://doi.org/10.1177/0300060519 895355.

Herman H, Nurshal D, Oktarina E (2017). Hubungan karakteristik remaja dengan perilaku bullying pada siswa SMP di Kota Padang (The relationship between adolescent characteristics and bullying behavior in Junior High School students in Padang). Jurnal Keperawatan Soedirman. 12(1): 1-11. http://dx.doi.org/10.20884/1.jks.201 7.12.1.677.

Jadambaa A, Thomas HJ, Scott JG, Graves $\mathrm{N}$, Brain D, Pacella R (2019). The contribution of bullying victimisation 
to the burden of anxiety and depressive disorders in Australia Epidemiol Psychiatr Sci. 29: e54. https://doi.org/10.1017/s2045796019000489.

Karlinda K, Tamtomo DG, Murti B (2019). Obesity and diabetes mellitus as predictors of mortality in patients with stroke: A Meta Analysis. Indones J Med. 4(4): 383-393. https://doi.org/10.26911/theijmed.2019.04.04.12.

Kaur J, Cheong SM, Naidu BM, Kaur G, Manickam MA, Noor MM, Ibrahim N, et al. (2014). Prevalence and correlates of depression among adolescents in Malaysia. Asia Pac J Public Health. 26(5): 53S-62S. https://doi.org/10.1177/1010539514544356.

Låftman SB, Alm S, Sandahl J, Modin B (2018). Future orientation among students exposed to school bullying and cyberbullying victimization. Int $\mathrm{J}$ Environ Res. 15(4): 605. https://dx.doi.org/10.3390\%2Fijerph15040605.

Landstedt E, Persson S (2014). Bullying, cyberbullying, and mental health in young people. Scand J. 42(4): 393399. https://doi.org/10.1177\%2F1403494814525004.

Le HTH, Nguyen HT, Campbell MA, Gatton ML Tran NT, Dunne MP 2016). Longitudinal associations between bullying and mental health among adolescents in Vietnam. Int $\mathrm{J}$ Public Health. 62(1): 51-61. https://doi.org/10.1007/s00038-016-0915-8.

Lemstra ME, Nieslen G, Rogers MR, Thompson AT, Moraros JS (2012). Risk indicators and outcomes associated with bullying in youth aged 9-15 years. Can J Public Health. 103(1): 913. https://doi.org/10.1007/bfo3404061.

Nansel TR, Craig W, Overpack MD, Saluja G, Ruan WJ (2004). Cross-national consistency in the relationship between bullying behaviors and psychosocial adjustment. Arch pediatr adolesc med. 158(8): 730-736. https://doi.org/10.1001/archpedi.158.8.730.

Naveed S, Waqas A, Aedma KK, Afzaal T, Majeed MH (2019). Association of bullying experiences with depressive symptoms and psychosocial functioning among school going children and adolescents. BMC Research Notes. 12(1): 10-13. https://doi.org/10.1186/s13104-019-4236-x.

Nindrea RD (2016). Pengantar LangkahLangkah Praktis Studi Meta Analisis (Introduction to Practical Steps of Meta-Analysis Studies). Yogyakarta: Gosyen Publishing.

Pranjić N, Bajraktarević A (2010). Depression and suicide ideation among secondary school adolescents involved in school bullying. Primary Health Care Research and Development. 11(4): 349-362. https://doi.org/10.1017/S1463423610000307.

Rahman MM, Rahman M, Khan MMA, Hasan M, Choudhury KN (2020). Bullying victimization and adverse health behaviors among school-going adolescents in South Asia: Findings from the global school-based student health survey. Depression and Anxiety. 37(10): 995-1006. https://doi.org/10.1002/da.23033.

Razak MAA, Ahmad NA, Aziz FAA, Jamaluddin R, Sidik SM, Awaluddin, Ibrahim $\mathrm{N}$, et al. (2019). Being bullied is associated with depression among Malaysian adolescents: Findings from a cross-sectional study in Malaysia. Asia Pac J Public Health. 31(8): 30S37S. https://doi.org/10.1177/1010539519867796.

Schneider SK, O’Donnel L, Stueve A, Coulter RWS (2012). Cyberbullying, school bullying, and psychological distress: A 
regional census of high school students. Am J Public Health. 102(1): 171-177. https://dx.doi.org/10.2105\%2FAJPH.2011.300308.

Selkie EM, Kota R, Chan YF, Moreno M (2015). Cyberbullying, depression, and problem alcohol use in female college students: A multisite study. Cyberpsychology, Behavior, and Social Networking. 18(2): 79-86. https://doi.org/10.1089/cyber.2014.0371.

Sivaraman B, Nye E, Bowes L (2018). School-based anti-bullying interventions for adolescents in low and middle-income countries: A systematic review. Aggression and Violent Behavior. 45: 154-162. https://doi.org/10.1016/j.avb.2018.07.007.

Sudrajad K, Soemanto RB, Prasetya H (2020). The effect of bullying on depression, academic activity, and communication in adolescents in Surakarta: A multilevel logistic regression. J Health Promot Behav. 5(2): 7986. https://doi.org/10.26911/thejhpb.2020.05.02.02.

Tan LA, Ganapathy SS, Sooryanarayana R (2019). Bullying victimization among school-going adolescents in Malaysia:
Prevalence and associated factors. Asia-Pacific Journal of Public Health. 31(8): 18S-29S. https://doi.org/10.1177\%2F1010539519870665.

Wang J, Nansel TR, Iannotti RJ (2011). Cyber and traditional bullying: Differential association with depression. $\mathrm{J}$ Adolesc Health. 48(4): 415-417. https://dx.doi.org/10.1016\%2Fj.jadoh ealth.2010.07.012.

Weng X, Chui WH, Liu L (2017). Bullying behaviors among macanese adolescents-association with psychosocial variables. Int $\mathrm{J}$ Environ Res Public Health. 14(8): 887. https://doi.org/10.3390/ijerph14080887 .

Wilson ML, Bovet P, Wiswanathan B, Suris JC (2012). Bullying among adolescents in a sub-Saharan middle-income setting. J Adolesc Health. 51(1): 96-98. https://doi.org/10.1016/j.jadohealth. 2011.11.024.

Zhang H, Chi P, Long H, Ren X (2019). Bullying victimization and depression among left-behind children in rural China: Roles of self-compassion and hope. Child Abuse and Neglect. 96: 104072. https://doi.org/10.1016/j.chiabu.2019.104072. 